\title{
Polymorphism of the renin-angiotensin system genes and endothelial no-synthase gene in obese patients with arterial hypertension
}

\author{
T. V. Ashcheulova, N. N. Gerasimchuk, G. V. Demydenko, M. V. Kulikova \\ Kharkiv National Medical University \\ 4, Nauki Ave., Kharkiv, Ukraine, 61001 \\ nino.gerasimchuk@gmail.com
}

The review is dedicated to relationships between the blood pressure and body mass. Endothelial dysfunction and imbalance of neurohumoral systems, namely, the pathological increase in the activity of the renin-angiotensin system, in combination with obesity are the main mechanisms of the of the hypertonic disease pathogenesis. Here we discuss the research on polymorphism of the renin angiotensinic system genes and the endothelial synthase nitric oxide gene. The difficulty lies in the correct assessment of associations of alleles which have clinical significance. It is essential to determine precisely the associations of gene polymorphisms in the hypertonic disease with obesity. This provides an opportunity to identify new personified approaches to the treatment of patients with this complex pathology.

Ke y w or d s: endothelial nitric oxide synthase, renin-angiotensin system, gene polymorphism, hypertonic disease, obesity.

\section{Introduction}

Genetic polymorphism is the presence of alleles, different variants of one gene, in a population. Herewith the allele can be considered as polymorphism, if the frequency of its occurrence in the population is not less than $1 \%$. Human genome polymorphisms are decisive for the development, progression and therapeutic intervention for various pathological conditions. Polymorphisms in different genes contribute to functional changes in the protein activity or expression. Therefore, it is important to clarify not only the effect of individual polymorphisms on the function of genes, but also the relationship between polymorphisms in different genes, especially those that are functionally related [1]. The structure and activity of the protein products of the gene may depend on the variant of the allele.

It is generally believed that the environmental and genetic factors influence the formation of arterial hypertension ( $\mathrm{AH})$ phenotype and determine its progression. At present, a significant role in the pathogenesis of polygenic diseases, in particular, arterial hypertension $(\mathrm{AH})$, is given to genetic polymorphisms. A number of studies have revealed the connec-

(C) 2018 T. V. Ashcheulova et al.; Published by the Institute of Molecular Biology and Genetics, NAS of Ukraine on behalf of Biopolymers and Cell. This is an Open Access article distributed under the terms of the Creative Commons Attribution License (http://creativecommons.org/licenses/by/4.0/), which permits unrestricted reuse, distribution, and reproduction in any medium, provided the original work is properly cited 
tion between numerous polymorphic markers of genes, coding the components of the reninangiotensin-aldosterone system (RAAS), the sympathoadrenal system (SAS), endothelial and other factors with the AH development.

All over the world, hypertension (HD) occupies a leading place in the structure of cardiac pathology and, due to its spreading among people of working age and early development of complications that lead to prolonged disability and invalidization is an urgent medical and social problem. Arterial hypertension (AH) as a starting and modelling mechanism induces the development of pathological changes in the cardiovascular system and internal organs [1]. At present, AH goes beyond medical problems taking a multidisciplinary and socially significant character.

The risk of complications and death in the $\mathrm{AH}$ patients increases according to numerous concomitant risk factors. AH in isolated form occurs only in $8 \%$ of cases, whereas in others it is combined with one or more factors of cardiovascular risk. In 20-22\% of cases AH is combined with hyperlipidemia, in $30 \%$ with hyperlipidemia and obesity, whereas $32 \%$ of patients suffered from dyslipidemia, obesity and various disorders of carbohydrate metabolism - glucose intolerance, insulin resistance, 2nd type diabetes mellitus (DM type 2) [2].

There are many researches on the genetic mechanisms of susceptibility to cardiovascular disease (CVD). Recently, it has been proved that genetic predisposition contributes to the inheritance of $\mathrm{AH}$. The genetic factors can play a significant role in the development of $\mathrm{AH}$ confirming its polygenic nature. Therefore, the search for the genetic markers of the renin- angiotensin system ( RAS) responsible for the development of $\mathrm{AH}$ and related disorders, namely obesity, and carbohydrate metabolism is an urgent problem of great interest to many scientists. The genetic polymorphism [3] is proved to be a significant factor affecting a level of expression of endothelial nitric oxide synthase (eNOS). The level and activity of NO depend on the allelic variant of the NO synthesis genes. In this regard, the study on the genes involved in the synthesis of NO (primarily eNOS) has become an important step in identifying the genetic risk factors for CVD. Their study is complex because of the large number of genes that can participate in the formation of hereditary predisposition either independently or through interaction with each other. Recently, a huge amount of information has been accumulated regarding polymorphic regions of the human genome as a whole, as well as their correlation with various diseases.

Modern strategy for researching a genetic predisposition is based on the study of the polymorphic markers of candidate genes. These are genes, the expression products of which are involved in the pathogenesis of this disease. Importantly, the genetic predisposition to such multifactorial pathologies, as $\mathrm{AH}$ and obesity is also polygenic, which requires an assessment of the integrated genetic panel. To clarify the nature of the link between the gene and metabolic state of the organism, single nucleotide polymorphisms (SNPs) are investigated. SNPs are defined as loci with alleles that differ at a single base, with a frequency of at least $1 \%$ in a random set of individuals in the population [4].

Nowadays, the polymorphism of dozens of genes has been found that claims the role of 
hereditary markers of atherosclerosis, $\mathrm{AH}$, coronary heart disease (CHD), myocardial infarction, chronic heart failure (CHF), and microvascular complications in type 2 diabetes, namely, diabetic retinopathy and nephropathy $[5,6]$. However, their clinical and prognostic values are not completely comprehensible; besides, the literature data are obviously contradictory.

The pathogenesis of hypertensive disease (HD) in obese persons is a multicomponent process, including an increase of circulating blood volume, vasoconstriction, and hyperactivity of sympathoadrenal, renin angiotensin systems, and metabolic disorders. One of the early phases of the pathogenesis of this complex pathology is the development of endothelial dysfunction (ED).

Due to the fact that the leading mechanisms for the development of cardiovascular disease are ED and the imbalance of the neurohumoral systems of the body, in particular the pathological increase in the activity of the renin-angiotensin system (RAS), it is the search and study of the polymorphisms of the genes of these systems is the most relevant today.

The genome-wide association studies (GWASs) have identified thousands of genes and genetic variants (mainly SNPs) that contribute to the complex diseases in humans. At the heart of the GWAS-based approaches lies the "common variant-common disease" hypothesis. The arrival of Next-Generation Sequencing (NGS) technologies facilitated a shift in focus from common to rare variants and provided the opportunity to unravel the genomic architecture underlying a hypertension risk.
Neurohumoral system in regulation of vascular tone and endothelial-dependent vasodilation in patients with hypertonic disease with obesity

The main components of the renin-angiotensin system (RAS) are angiotensinogen (AGT), angiotensin converting enzyme (ACE) and angiotensin II (AT II) in patients with AH.

For many decades considerable attention has been paid to determining the role of RAS in the development of cardiovascular disorders, namely in the pathogenesis of AH. RAS plays a special role in vasoconstriction and vasodilation, regulating long-term blood pressure. Juxtaglomerular kidney cells secrete the enzyme renin. Renin proteolizes the inactive peptide of angiotensinogen, converting it into angiotensin I (AT I). AT I is then transformed into AT II using ACE.

AT II is one of the strongest vasoconstrictors. In kidneys, AT II leads to the contraction of glomerular arterioles, thus changing the glomerular filtration rate. In the adrenal cortex, AT II causes the release of aldosterone, which in turn affects the renal tubules, which leads to reabsorption of the majority of sodium and water ions from the urine due to displacement of potassium ions in the renal tubules. Aldosterone also affects the central nervous system, increasing the appetite of humans to salt and causing a feeling of thirst. Besides, AT II is able to increase the inflammatory potential, to provoke oxidative stress and endothelium dysfunction, to activate atherogenesis [7].

Two types of receptors are involved in the implementation of AT II influence on the heart and blood vessels. The receptors of AT II type 1 (AT1 receptors) mediated the main physi- 
ological and pathophysiological effects of AT II whereas the role of type 2 receptors (AT2 receptors) remains controversial. Under normal conditions, they are present in a small amount in the vascular endothelium, but their expression significantly increases in various pathological conditions associated with inflammation and remodelling of the heart and vessels: $\mathrm{AH}$, atherosclerosis, DM type 2, myocardial infarction [8].

It was determined that AT II participates in the regulation of growth and development of adipose tissue [9]. Today it is known that the formation of AT II is not limited to the system circulation, it can be synthesized in a variety of tissues. In recent years much attention has been paid to adipose tissue, which is no longer considered only as an energy depot.

The increased levels of adipocyte-secreted angiotensin are an important link between visceral obesity and ED, as evidenced by the correlation between the "waist circumference / hip circumference" and the level of RNA angiotensinogen (AGT) of visceral and subcutaneous adipose tissue. Further enhancement of the AT II production at the tissue level stimulates the secretion of superoxide - a leading factor in the etiology of ED. Thus, the activation of vascular RAS in subjects with abdominal obesity should be considered as a leading mechanism of ED [10].

At present, the leading role of endothelium and nitric oxide (NO) in the genesis of cardiovascular complications of HD has been proven. Endothelium is rightly called the largest endocrine gland of the body.

In physiological conditions, there is predominance of secretion of substances that cause relaxation, one of which, nitric oxide
(NO) controls the basal tone of arterial vessels and, as a consequence, the blood pressure level. NO is a universal regulator of physiological functions, in particular a powerful vasodilator. For $\mathrm{HD}$, the main factor in the development of ED is the reduction of NO synthesis with preserved or increased secretion of vasoconstrictors (endothelin-1, angiotensin II), which aggravate endothelium-dependent relaxation, lead to the degradation and changes in the cytoarchitectonics of blood vessels. The main target of $\mathrm{NO}$ is soluble guanylate cyclase, the heme of which is a receptor for NO. The heme-linked NO induces soluble guanylate cyclase, which leads to the enhanced synthesis of cyclic guanosine monophosphate (cGMP). Nitric oxide is formed in endothelial cells from L-arginine under the action of enzymes of the NOsynthase system - constitutional neuronal (NO-synthase type 1, NOS 1 or nNOS), "inducible" (NO-synthase type 2, NOS 2 or iNOS) and constitutional endothelial (NOsynthase type 3 , NOS 3 or eNOS). In the active form all three isoforms are homodimers having a molecular weight of 130 (iNOS), 135 (eNOS) and 160 (nNOS) kDa [11]. The formation of $\mathrm{NO}$ is regulated by altering the expression or activity of the eNOS enzyme itself, as a result, of changes in the activity of either cofactors, or endogenous inhibitors.

A number of studies have shown that a deficiency of NO in the blood leads to a number of CVDs. The risk of AH significantly increases with the excess body weight and obesity. Body mass closely correlated with BP. In some studies at the population level, it has been shown that overweight is an independent risk factor for hypertension. In recent years, 
the term "obesity-induced hypertension" has appeared [12].

In connection with the study of mechanisms that regulate energy metabolism and provide neurohumoral homeostasis, new concepts have been rebuilt for the presence of pathogenetic links between excess body weight and increased levels of blood pressure (BP). The effect of excess body weight on the level of BP depends on the genetic and neurobiological mechanisms that underlie the development of obesity.

Obesity contributes to the development of $\mathrm{AH}$, and $\mathrm{AH}$ can cause a decrease in the sensitivity of peripheral tissues to insulin and further obesity [13]. The probability of development of $\mathrm{AH}$ in persons with excess body weight is $50 \%$ higher than in those with normal body mass (Framingham Study) [14]. About $75 \%$ of cases of AH are associated with obesity, but the mechanism by which it promotes the development of AH is not yet fully studied. A rise in body weight by $5 \%$ increases the risk of AH by $30 \%$ over four years. The frequency of $\mathrm{AH}$ increases to $55 \%$ in those who had BMI greater than $30 \mathrm{~kg} / \mathrm{m}^{2}$ regardless of gender and age [15]. In a number of observations, attention was drawn to the fact that along with the degree of obesity a significant factor in the cardiovascular disease is a mode of the distribution of adipose tissue. It is abdominal obesity [16], which is mainly located in the upper half of the body more often than the accumulation of fat in the lower half of the body (hyoid or peripheral), is combined with cardiovascular disease and mortality, accompanied more often by a violation of glucose tolerance, diabetes mellitus and dyslipidemia.

\section{Polymorphism of the renin- angiotensin system genes and cardiometabolic risk}

One of the key components of RAS is angiotensin converting enzyme (ACE). Normally, in different people, the ACE levels in blood plasma can vary up to 5 times. In a particular person, the ACE level is fairly stable. Such fluctuations in the level of ACE among people are caused by the polymorphism of the $A C E$ gene. The $A C E$ gene is charted in chromosome $17 \mathrm{q} 23$. In the 16th intron of the $A C E$ gene, an insertion-deletion (I/D) polymorphism (rs1799752) was found, which is one of four SNPs representing perhaps the best studied $A C E$ SNP. It is actually not a single nucleotide polymorphism at all; instead, it is an insertion/ deletion of an Alu repetitive element of 287 pairs of nucleotides in intron of the $A C E$ gene. Alleles containing the insertion are called " $P$ " alleles, and " $D$ " alleles lack the repetitive element. The Alu-repeat deletion results in an increase in the expression of the $A C E$ gene. In this case, there was a correlation between $D$ alleles and the level of ACE in blood, lymph and tissues. The level of ACE in serum in healthy people who are homozygous for $D$ allele ( $D D$ genotype was observed in approximately $36 \%$ of people) was almost twice as high as in homozygous for $I$ allele (II - genotype, about $17 \%$ of people) and had an average value in heterozygous - ID genotype (47\%). The gene polymorphism is also associated with ACE level in the human heart.

Thus, the presence of allelic variant $D$ leads to an increased content of angiotensin II, a decrease in the level of bradykinin and may be a risk factor for the development of cardiovascular disease [16]. 
To date, a number of data on the association of the $A C E$ gene polymorphism with myocardial infarction, sudden death, hypertension, left ventricular hypertrophy (LVH), hypertrophic cardiomyopathy, endothelial dysfunction, kidney disease and microvascular complications of diabetes mellitus have been accumulated $[16,17]$. In particular, it was found that the presence of allele $D$ in the genotype of patients was associated with higher levels of BP (both systolic and diastolic), predisposition to the crisis course of hypertension and a significantly higher severity of left ventricle myocardial hypertrophy. The presence of genotype II in patients with hypertension, on the contrary, was associated with its asymptomatic course and a significantly later age of manifestation [18]. Additionally, it has been shown that the genotype $D D$ is more common in the patients with CHD, diabetes mellitus and other risk factors (hyperlipidemia, smoking, family history of CVD) $[16,17,19]$. The $D D$ variant of the genotype was associated with any myocardial infarction, as well as a stroke and the development of AH [20].

The data of another study show that in the survey of a fairly large population (3145 people) in the framework of Framingham study, it was found that the presence of the $D$-allele of the $A C E$ gene in men is associated with a higher level of BP, especially the marked association of $D$-allele was observed with the level of DBP. For women, such patterns were not found [21].

On the other hand, there is also evidence of the absence of association of the $A C E$ polymorphism with hypertension. Later, the same author established that the connection is absent in the groups with a milder degree of hyperten- sion, and in the persons with a malignant form of the $D D$ genotype it occurs 3 times more often. The results of the initial studies were subsequently called into question in more extensive studies and through using randomized and well-organized groups. As a rule, many researchers do not take into account the population and ethnic features of clinical material. In multifactorial diseases, the genetic system of polygenes is represented by a huge polymorphism of alleles of genes, the effects of which may be separately not so significant or manifested in certain circumstances. And because of ethnic diversity and high migration of people with different forms of hypertension it is impossible to bring the results to a common denominator. Therefore, the choice of methods for detecting the connection between polymorphisms with $\mathrm{AH}$, the features of the studied groups, as well as the effect of hidden causes that determine the levels of BP and diagnosis of AH may be decisive in the findings of the study.

The results showing the contingency of the allele $D$ with the presence of abdominal obesity were obtained. The relationship between abdominal obesity and the diagnosis of $\mathrm{AH}$ was of linear symmetric and mean strength. Thus, one can judge common genetic component in the implementation of hypertensive disease and abdominal obesity [22].

Interesting data on the association of polymorphism of the $A C E$ gene with endothelial dysfunction, as well as the processes of vascular wall remodeling and atherogenesis are available. An increase in the activity of the local endothelial ACE is associated with a disturbed endothelium-dependent vasodilatation on acetylcholine in the hereditary $\mathrm{AH}$ of 
rats. This suggests that local hyperactivity of RAS can lead to the endothelial dysfunction.

On this basis, the attempts were made to link the endothelium dysfunction with the genotype of $A C E$. F.Perticone studied vasodilation of the brachial artery in the patients with HD and healthy individuals in response to infusion of acetylcholine (endothelial-dependent vasodilation) and sodium nitroprusside (endothelial-independent stimulus). At the same time, in the group of people with $\mathrm{AH}$ endothelial-dependent vasodilation was significantly less in the patients with $D D$ genotype compared with the patients with $I I+I D$ genotype. In this case, endothelialindependent vasodilation in these groups of patients did not differ significantly. Thus, the patients with $D D$ genotype showed a greater degree of endothelial dysfunction, although they did not differ from the patients with II and ID genotypes in the level of BP, age, parameters of daily BP monitoring. In the group of healthy control such regularities were not revealed.

Among numerous candidate-genes, the type 1 receptor gene to angiotensin II (AGTRI) also attracts attention because it mediates not only the vasoconstrictive action of angiotensin II, but also the expression of growth factors, the proliferation of smooth muscles, the release of tissue activator inhibitor Plasminogen and a number of other important effects [23].

Thus, the changes in expression or structure of the angiotensin II receptor of type 1 due to the polymorphism of its gene may lead to the changes in the regulation of vascular tone or proliferation of the elements of the vascular wall, so the gene of the angiotensin II receptor type 1 is considered as one of the candidate- genes, associated with the pathology of the cardiovascular system.

The gene encoding the 1st type angiotensin II receptor (AGTRl) is located on chromosome 3 (3q24). The most actively studied is polymorphism $A 1166 C$ (rs5186, a SNP known as $+1166 \mathrm{~A} / \mathrm{C}$ or $\mathrm{A1166C}$, is located in the 3 ' untranslated region of the angiotensin II receptor type 1 gene $A G T R 1$ ), which leads to the replacement of adenine (A) with cytosine (C) in the 1166 position of the AGTR1 gene. B. Bonardeaux et al. have proved that the mutation precisely in the 1166 th position of the nucleotide sequence of the $A G T R 1$ gene affects the functional activity of the receptor type 1 of angiotensin II. Polymorphism of A1166C in $A G T R 1$ was associated with CHD, as well as with myocardial infarction and the development of AH [24].

There are interesting results of the study on the pulse wave velocity propagation and evaluation of the stiffness of large arteries in people with $\mathrm{AH}$ and healthy people, depending on the genotype. The increased stiffness of the aorta with high probability was associated with the $1166 C C$ genotype in people with $\mathrm{AH}$.

Such a connection was not observed in people with normal pressure. The multiple regression analysis showed that the genotype of the angiotensin II receptor type 1 is the second after SBP level most important determinant of aortic stiffness [25].

Equally important component of RAS is the protein - angiotensinogen (AGT).

The $A G T$ gene is localized in the first chromosome (locus 1 q42-43). In 1992, $\mathrm{H}$. Jeunemaitre et al. for the first time confirmed the correlation between the $A G T$ gene polymorphism and $\mathrm{AH}$ among Europeans and 
Americans. 15 variants of the $A G T$ gene were identified, but the association with the plasma levels of AGT and hypertension was detected only for both point mutations with the replacement of threonine with methionine and methionine with threonine in 174 and 235 gene codons - T174M (rs 4762, which is commonly referred to in the literature as "T174M" or "Thr174Met"; however, databases now indicate that the amino acid that varies is \#207 (not 174 , as the protein is currently numbered) and M235T (rs699, that is a SNP in the angiotensin AGT gene that encodes a functional change ??. In most published works, the name for this SNP is M235T, or perhaps Met235Thr, however its amino acid 268 (not 235) that varies based on the numbering in todays databases. rs699 is also occasionally known as C4072T. In any case, the rs699(C) allele encodes the threonine variant, which is associated with higher plasma angiotensin levels, and ultimately higher blood pressure leading to an increased risk for the hypertension associated disorders [17]), respectively, associated with the AGT activity levels of blood plasma, with the content of AT II and, consequently, with the risk of CVD. According to the literature, the presence of a $174 M$ allele of the $A G T$ gene is much more common in the patients with $\mathrm{CHD}$, with myocardial infarction and LV hypertrophy [26]. In study on the M235T polymorphism, it was found that variant $235 T$ is an independent factor in the risk of developing a heart attack, a risk factor for CHD. At the same time, it was found that the presence of one or two $T$-alleles led to a substantial increase in the level of AGT in plasma, resulting in a higher content of angiotensin II. It is a reason by which many authors explain the association of this polymorphism with $\mathrm{AH}$. Sethi A. et al. conducted a meta-analysis, the purpose of which was to study the association of the $A G T$ gene $M 235 T$ polymorphism with the concentration of angiotensinogen in blood plasma, the level of systolic blood pressure (SBP) and diastolic blood pressure (DBP), $\mathrm{AH}$ and the risk of developing myocardial infarction and CHD. The study included three major ethnic groups: representatives of the Caucasian, Mongoloid and Negroid races. In representatives of Caucasian races an increase in the concentration of AGT in plasma by $5 \%$ in $M T$ heterozygotes and by $11 \%$ in homozygotes in the $235 T$ allele was noted compared with the carriers of $M M$ genotype. The M235T polymorphism of the $A G T$ gene is associated with the risk of developing $\mathrm{AH}$ in Caucasians and indigenous people in Asia. However, in all three ethnic groups, this polymorphism was not associated with the risk of developing myocardial infarction and CHD [27].

Additionally, according to other studies, there is a correlation between the TT genotype of the M235T polymorphism of the $A G T$ gene with a higher probability of development of $\mathrm{AH}$, higher levels of BP and of concentration of ACE [28]. In another study of the M235T polymorphism it was demonstrated that the presence of one or two T-alleles is accompanied by a significant increase in the level of AT II, which in turn, is able to trigger a cascade of inflammatory reactions, leading to various disorders.

There is also an evidence of a correlation between the frequency of $T / M$ allele of the $M 235 T$ polymorphism of the $A G T$ gene in hypertensive patients, which is $0.73 / 0.27$. That is, the frequency of $T$-allele is almost twice higher in the patients suffering from AH [29]. 
The $M 235 T$ polymorphism of the $A G T$ gene can promote the activation of immune inflammation in the patients with AH. Thus, it was demonstrated that $\mathrm{AH}$ occurs and deepens in the individuals who are carriers of the gene of the $T$-allele of the M235T polymorphism of the $A G T$ gene when the cytokine-interleukine-1 (IL-1) and TNF- $\alpha$ concentrations are elevated. A high level, in particular IL-1, can promote inflammation, higher expression of AGT, and vasoconstriction of vessels in the patients with $\mathrm{AH}$. That is, the M235T polymorphism of the $A G T$ gene is a significant risk factor and a hereditary marker of the $\mathrm{AH}$ development [30].

\section{Characteristics of endothelial nitric oxide synthase gene polymorphisms of G894T, T-786C and 4th intron}

At present, a significant amount of data on the association of polymorphisms of the eNOS gene with various diseases, including CVD, has been accumulated.

$\mathrm{NO}$ of endothelial origin is an important atheroprotector mediator, and the disorder of the regulation of its synthesis is associated with an increased risk of CVD. Hypertension develops in the NOS mouse line, and atherosclerosis develops in the line combining the absence of a functioning apolipoprotein $\mathrm{E}$ gene and the NOS gene (NOS3 is also known as eNOS) in the genome. Therefore, the processes of regulation of the synthesis of $\mathrm{NO}$ and the gene encoding the NOS, are the first candidates in the study of endothelial dysfunction of blood vessels and a number of CVD [31]. Among the genes encoding NOS, the most likely candidate for the development of CVD is precisely the NOS3 gene.
The eNOS enzyme and NOS3 gene were described in 1992-1993. The gene encoding the eNOS is located on the chromosome 7q3536 and consists of 26 exons [32]. The eNOS gene promoter contains several domains, i.e. it can be controlled by a number of transcription factors [33]. To date, the polymorphism of the eNOS gene in 11 locations has been described, 8 of which were studied as possible risk factors for CVD [34]. The most studied are the $4 a / b$ polymorphism of 4 th intron (27-bp-VNTR), the G894T (Glu298Asp) (rs1799983) polymorphism of the 7th exon and the $T-786 C$ (rs2070744) polymorphism of the eNOS gene promoter [35,36]. Fig. 1 .

The DNA region of the NOS3 gene, in which guanine $(G)$ is replaced by thymine $(T)$ in position 894, is called the genetic marker G894T. As a result of such a substitution, the properties of the protein are transformed, because in its amino acid sequence the glutamic amino acid at position 298 is replaced by asparaginic acid (Glu298Asp). The possible genotypes are $G / G ; T / T ; G / T$. A number of studies have shown that the people with genotype $T / T$ have a higher risk of coronary heart disease (CHD), myocardial infarction and ischemic stroke. This is especially true in modern life, when the cardiovascular system of a person is constantly subjected to various stresses. On the background of the genetic predisposition to CVD (the presence of allele $T$ on $S N P$ $G 894 T$ of the NOS3 gene in the genotype) a probability of the pathology development increases. The $T$-allele carriers $(T / T$ and $G / T$ genotypes) are more common in pregnant women who suffer from hypertension and placental abruption, compared to the group of women without these complications of preg- 


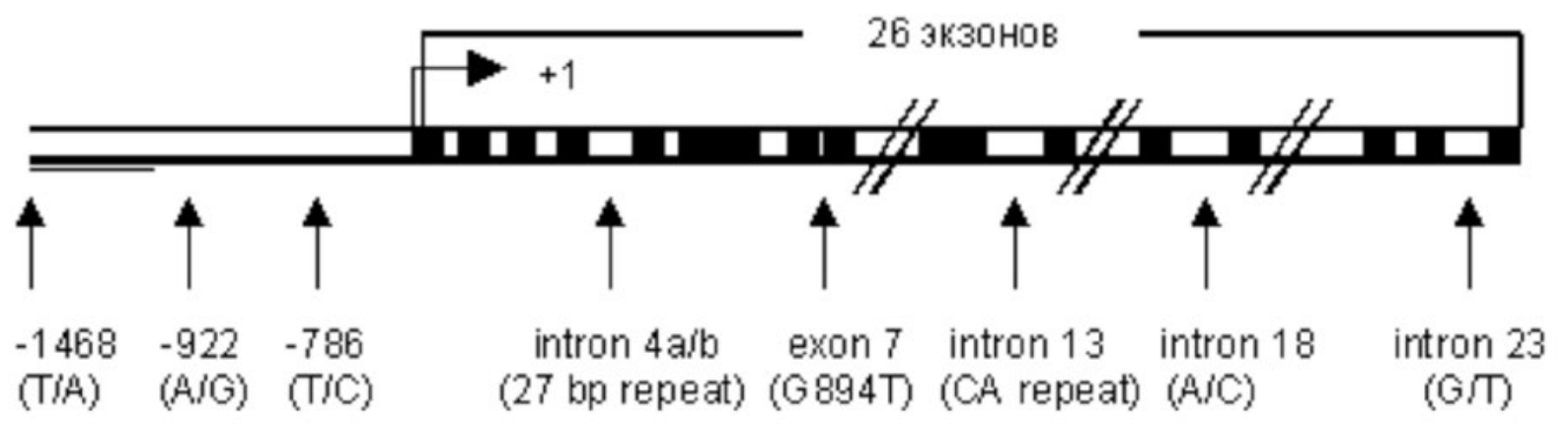

Fig. 1. Polymorphism of the endothelial $N O$ gene of synthase (eNOS)

nancy. Thus, the presence of $T$-allele is a potential independent factor that increases the risk of developing hypertension in pregnancy [37].

The literature presents contradictory information on the relationship between the alleles of the polymorphism G894T and the content of NO in the blood. So, according to Dias R.G. et al [38], the TT genotype of G894T polymorphism causes an increase in the proteolytic activity in endothelial cells, leading to a decrease in the levels of functional eNOS and nitric oxide, and Sakar M. N. et al. [39] showed that the individuals with the $T T$ genotype have statistically significantly lower NO level compared to the subjects with $G G$ or $G T$ genotypes $(\mathrm{p}<0.05)$. At the same time, Mackawy A.M. et al [40] found that the allele $T$ of $G 894 T$ polymorphism is associated with elevated levels of nitrates in plasma: the content of plasma nitrates in the individuals with genotypes $G G$, $G T$ and $T T$ was $9.92 \pm 1.65 ; 12.11 \pm 1.04$; $14.55 \pm 2.18 \mathrm{mmol} / \mathrm{ml}$, respectively. In this regard, additional studies with a large number of subjects are needed to clarify this issue.

It is proved that the modification of the eNOS gene polymorphism is associated with the oxidative stress [41]. The role of gene polymorphism, in particular NOS3 (Glu298Asp), and end-product of glycosylation in the differential response of cells to hyperglycemia has been studied. It is shown that the presence of this genotype contributes to the development of endothelial-dependent vascular complications [42]. Several authors found that the G894T polymorphism of the NOS3 gene is a risk factor for coronary atherosclerosis and HD. At the same time, there may be a connection between the allele $G$ of Glu298Asp polymorphism and the age of individuals with AH [43]. It has been shown that the polymorphism of eNOS - Glu298Asp (rs1799983) is associated with the BP levels in adolescents [44]. Besides, numerous studies have found that the endothelium dependent vasodilatation in the presence of the 298Asp (894T) allele is damaged, and this type of polymorphism is connected with CHD and hypertension.

Thus, it has been established that G894T polymorphism is associated with an increased carotid intimal medial thickness in the right carotid artery [45]. The association of the TT genotype with angina pectoris (odds ratio $(\mathrm{OR})=10.2 ; 95 \%$ confidence interval 
$(\mathrm{CI})=1.51-68.8 ; \mathrm{P}=0.025)$ was found; in turn, the highest frequency of genotype $G T$ occurrence was revealed in the individuals, who had relatives with coronary artery disease [46].

An analysis of literary sources on the databases of Medline, Embase and Wangfang by January 1, 2013 with the participation of 8547 patients and 9117 persons in the control group, showed that the genotype TT of G894T polymorphism is highly associated with the risk of developing ischemic stroke compared with the genotype of the allele $G(\mathrm{OR}=1.25,95 \%$ $\mathrm{CI}=1.09-1.42, \mathrm{P}<0.001)$, which is more relevant for the Asian race than for the Caucasian race [47]. A meta-regression analysis devoted to the establishment of associations between HD and the polymorphic variant of G894T in the Han ethnic group (China) showed a positive relationship $(\mathrm{OR}=1.32, \mathrm{P}<0.001)$, whereas geographic differences were identified in the relationship between $G 894 T$ and predisposition to this disease. Thus, among the residents of the southern regions of China the indicated polymorphism may be related to HD $(\mathrm{OR}=1.59, \mathrm{P}<0.001)$, whereas in the northern regions such association is not observed $(\mathrm{OR}=1.16, \mathrm{P}=0.12)$ [48].

In the individuals suffering from excessive body weight, the T allele of the G894T polymorphism of the NOS3 gene increases the risk of hypertension development [49]. There was established an increased risk of developing obesity in the presence of the TT G894T genotype $(\mathrm{OR}=2.62, \mathrm{P}=0.04)$, whereas the gender analysis shows that in men with overweight this genotype is found much more often compared to the control group $(9.9 \%$ versus $2.9 \%, \mathrm{P}=0.01)[50]$.
Moreover, the authors investigated the relationship between the main effector of the renin-angiotensin system AT II and allelic polymorphism G894T of the eNOS gene. It has been established that this type of polymorphism determines the systemic and renal hemodynamic response to AT II. This effect is more pronounced in men than in women [51]. In this regard it is of scientific and practical interest to study the combined effect of the common polymorphism on the insertion/deletion of the $A C E$ gene and the allele $894 T$ of the eNOS gene on the development of endothelial dysfunction, hypertension, atherosclerosis, and nephropathyis.

One of the most studied variants of the eNOS polymorphism is tandem repeats in the intron $4(4 a / b)(\mathrm{rs} 869109213$. In intron 4 of this gene minisatellite eNOS $4 a / 4 b$ is located, which has two alleles, consisting of 4 or 5 tandem repeats in size of 27 pairs of nucleotides. The normal version contains 5 repeats (denoted as $4 \mathrm{~b}$ ), the mutant variant contains 4 repeats (denoted as $4 a$ ).

The variants of polymorphism: $4 \mathrm{~b} / 4 \mathrm{~b}-$ normal variant of polymorphism in a homozygous form; $4 \mathrm{~b} / 4 \mathrm{a}$ - heterozygous form of polymorphism; $4 \mathrm{a} / 4 \mathrm{a}$ - mutant variant of polymorphism associated with the increased risk of disease in a homozygous form.

The effect of variant $4 \mathrm{a}$ is associated with a disorder of the expression of the NOS3 gene, which leads to a decrease in the NO production. For this variant, the associations with atherosclerosis, CHD and myocardial infarction are described. In the patients with type 2 diabetes, the presence of option $4 \mathrm{a}$ is a risk factor for hypertension. In 2004 S.Fatini et al. showed a connection between the genotype $4 \mathrm{a}$ 
/ 4a and the onset of acute coronary syndrome, in particular with an acute myocardial infarction [52]. Additionally, in 2012, Chinese scientists in the meta-analysis of American patients have linked the $4 \mathrm{a} / 4 \mathrm{a}$ genotype with an increased risk of ischemic stroke [53].

Most authors have shown that the presence of allele $\mathrm{C}$ in position 786 of the promoter of the $e N O S$ gene results in a decrease in its activity by $52 \pm 11 \%$, and the resulting lack of eNOS is responsible for a decrease in the synthesis and release of nitric oxide and endothelial dysfunction [54]. In the people with pathological genotype of the promoter of the eNOS gene $(C C$ and $T C)$ it was observed an increase in the tone of coronary arteries, increased propensity to coronar spasm and perverted coronary artery reaction to the introduction of acetylcholine, which can serve as the basis for the development of coronary heart disease (CHD) and HD [55]. It was shown that the polymorphism of $-786 T>C$ promoter is associated with an increased risk of restenosis after the stenting of coronary arteries [56].

When screening the population to determine the prevalence of $-786 T>C$ (rs2070744) polymorphism in the 5'- untranslated region of the gene $e N O S$ and its association with pathology, it was found that homozygotes $-786 \mathrm{C}$ are more common among the patients with atherosclerosis of the coronary arteries than in the control group ( $24.6 \%$ versus $14.5 \%)$. The risk of the pathology development was higher in the homozygote $C C$ compared with the homozygotes TT [57].

The association of polymorphism $-786 T>C$ with the type of vascular reaction to the load was also found among juvenile Caucasian race. In boys (168 persons) with a hypertensive response to the load the genotype of $C C$ was found 3.5 times more often. Such $C C$ homozygotes are characterized by a higher peripheral vascular tone and an imbalance of production of major vasoactive endothelial factors, which is manifested in elevated endothelin-1. It is typical that hypertonic vascular responses to load are noted in the individuals with a failure of regulatory mechanisms of supporting the vascular tone, as well as in those with HD and pre-hypertension [58].

Noteworthy, this study focused on the persons with for the moment compensated state of vascular factors, the imbalance of which is revealed only with certain tests. Distinguishing such a group with a hidden pathology of CVD and defining the NOS3 gene polymorphism in it would help to study the implementation of a particular allele in the phenotype.

Meta-analysis of Casas et al. showed that the mutation $-786 T>C$ in the promoter region of the eNOS gene affects the level of gene expression. A low level of the mRNA of the eNOS gene as well as a low serum nitrate/nitrite level are noted in the individuals with the variant $-786 C$ [59].

In Canada, 705 middle-aged men without CHD in their history were involved in the study of M.E. Hyndman et al. [60]. The ratio of different variants of the genotype (TT, TC, and $C C$ ) of the promoter of the eNOS gene was close to that of the Caucasians and was distributed respectively $38.9 ; 46.1$ and $15.0 \%$. The persons with $C C$ genotype had markedly higher levels of SBP and were more often diagnosed with $\mathrm{AH}$ which allowed the authors to conclude that the $C C$ genotype of eNOS gene promoter is a risk factor in the development of $\mathrm{AH}$. 
In 2013, the data on the association of eNOS gene polymorphisms 4b/4a, T-786C and G894T with metabolic syndrome (MS) have been published. The study included 339 patients with MS and 783 patients without MS who were treated at the Central Taiwanese Hospital. The variant $\mathrm{TC}+\mathrm{CC}$ on $\mathrm{T}-786 \mathrm{C}$ SNP of the eNOS gene was significantly associated with a decrease in the risk of MS $(\mathrm{OR}=0.63)$. Intron $4 \mathrm{~b} / 4 \mathrm{a}$ genotype of intron $427 \mathrm{bp}$ repeat polymorphism of the eNOS gene is also associated with a decrease in the risk of MS (OR=0.68). Additionally, the authors have shown that the presence of the G894T genotype in obese subjects plays a significant role in comparison with the control group $(\mathrm{OR}=1.65)$ [61]. J. Bressler, J.S. Pankow, J. Coresh, E. Boerwinkle analyzed the polymorphism of the eNOS gene (G894T) and obesity as a risk determinant for $\mathrm{AH}, \mathrm{DM}$ type 2 in 14,374 participants from the United States in the framework of a joint study in 2013. Among the participants there were 728 patients with DM type 2 (African-Americans) and 980 - of Caucasian race. The study shows that the relationship between the indicated parameters is noted only in the individuals of the Caucasian race [62].

Additionally it was noted that for the Italian population two types of the eNOS gene polymorphisms are associated with significant angiographical changes. The scientists suggest that the combination of two types of polymorphisms T786C and Glu298Asp in one genome is associated with a high risk of developing CHD and HD compared to one type [63]. Thus, this study demonstrates the importance of identifying not a single polymorphism, but their combination to distinguish the risk groups in CHD and HD.
A four-SNP haplotype, comprising an uncommon variant rs11699009 in the BPIFB4 gene, has been associated with notable longevity. In the study of Vecchione et al. [64], 416 individuals were genotyped to determine their haplotypes. The authors demonstrated that the overexpression of the BPIFB4 uncommon variant in mice impaired eNOS signaling and increased BP, opening the way for the development of new therapeutic strategies. The present study demonstrates that the expression of a rare variant of BPIFB4 - a protein we have previously associated with improved aging when present in its longevity-associated isoform - leads to the maintenance of high blood pressure in the face of treatment of hypertension.

Noteworthy, a number of studies did not reveal the relationship between the polymorphism of the NOS3 gene and the development of CVD, which may be due to the small sample size in these studies or ethnicity etc.

\section{Data from Next-Generation Sequencing technology at hypertension with obesity}

The cause of a complex trait, like essential hypertension, remains elusive if examined in the light of the GWAS results. Data from NGS technology offer the possibility to capture a greater range of the single nucleotide variability compared to GWAS.

Genetic variants associated with hypertension, obesity and diabetes based on PolyPhen2 and SIFT algorithmic predictors of mutation pathogenicity were analyzed on the complete exome of 60 people of Kazakh nationality using the technology of Next-Generation Sequencing (NGS) HiSeq2000. 
Seven genetic variants were detected in GHRL (rs4684677), MTHFR (rs 1801133), OPRM1 (rs1799971), ERBB2 (rs1058808), BDNF (rs6265), PNPLA3 (rs738409), MTRR (rs1801394) genes [65].

The group of Kim et al. [66] interrogated 135 Exome Chip SNVs for associations with ten cardiometabolic traits in 14,028 Korean individuals. Three associations were observed with one or more of four cardio-metabolic traits (fasting plasma glucose (FPG), waist-hip ratio (WHR), Systolic Blood Pressure (SBP), Diastolic Blood Pressure (DBP), within the genes BRAP, ACAD10 and $A L D H 2$ in the $12 \mathrm{q} 24.12$ region. The pleiotropic effect of region $12 \mathrm{q} 24.12$ was identified for three SNPs (rs3782886 on BRAP, rs 11066015 on ACAD10 and rs671 on $A L D H 2$ ) on lipids and other cardio-metabolic traits. The locus was also associated with High-Density Lipoprotein (HDL), Low-Density Lipoprotein (LDL), triglycerides $\left(\mathrm{p}<1.06 \times 10^{-2}\right.$; effect sizes between $-7.60 \pm 1.72$ and $2.55 \pm 0.53)$ [66].

\section{Conclusions}

The study on the polymorphism of the reninangiotensin system genes and the endothelial synthase nitrogen oxide gene is of great practical importance, since it not only provides an opportunity to predict the complications of hypertension disease but is also the basis for obtaining the expression of positive gene combinations. Thus, the analysis of literature data suggests that identified genotype-phenotype associations and corresponding functional changes in the endothelium can give information about the possibilities of priority and optimal therapeutic effects in each case, will enable optimization of the diagnosis of disor- ders in patients with combined pathology hypertension and obesity, at the early stages. The advent of Next-Generation Sequencing provided the opportunity to detect, in a highthroughput way, the entire spectrum of genomic variation ranging from rare to common variants and from Single Nucleotide Polymorphism to insertions, deletions.

However, the analysis of works on this subject showed that in studying the association of the polymorphism of the renin-angiotensin system genes and the endothelial synthase nitrogen oxide gene with the development of cardiovascular diseases, namely, hypertension with obesity, one must take into account both the ethnic belonging of the subjects and a composition of polymorphous variants, and their combinations in the sample of a larger size.

\section{REFERENCES}

1. Donev RM, Howell OW. Polymorphisms in neuropsychiatric and neuroinflammatory disorders and the role of next generation sequencing in early diagnosis and treatment. Adv Protein Chem Struct Biol. 2012;89:85-116.

2. World Health Organization. 2008-2013 Action plan for the global strategy for the prevention and control of noncommunicable diseases. WHO, Geneva, 2009:42

3. Casas JP, Cavalleri GL, Bautista LE, Smeeth L, Humphries SE, Hingorani AD. Endothelial nitric oxide synthase gene polymorphisms and cardiovascular disease: a HuGE review. Am J Epidemiol. 2006;164(10):921-35.

4. Keats BJB, Sherman SL Population Genetics. In: Emery and Rimoin's Principles and Practice of Medical Genetics. Academic Press (Sixth Edition). 2013: 1-12

5. Förstermann U, Münzel T. Endothelial nitric oxide synthase in vascular disease: from marvel to menace. Circulation. 2006;113(13):1708-14. 
6. Prasad A, Narayanan S, Husain S, Padder F, Waclawiw M, Epstein N, Quyyumi AA. Insertion-deletion polymorphism of the ACE gene modulates reversibility of endothelial dysfunction with ACE inhibition. Circulation. 2000;102(1):35-41.

7. Giacchetti G, Ronconi V, Turchi F, Agostinelli L, Mantero F, Rilli $S$, Boscaro M. Aldosterone as a key mediator of the cardiometabolic syndrome in primary aldosteronism: an observational study. $J \mathrm{Hy}$ pertens. 2007;25(1):177-86.

8. Heeneman S, Sluimer JC, Daemen MJ. Angiotensinconverting enzyme and vascular remodeling. Circ Res. 2007;101(5):441-54.

9. Leoncini $G$, Ratto E, Viazzi F, Vaccaro V, Parodi D, Parodi A, Falqui V, Tomolillo C, Deferrari G, Pontremoli $R$. Metabolic syndrome is associated with early signs of organ damage in nondiabetic, hypertensive patients. $J$ Int Med. 2005; 257(5):454-60.

10. Lahera V, Cachofeiro V, de Las Heras $N$. Interplay of hypertension, inflammation, and angiotensin II. Am J Hypertens. 2011;24(10):1059.

11. Andrew PJ, Mayer B. Enzymatic function of nitric oxide synthases. Cardiovasc Res. 1999;43(3):521-31.

12. Alberti KG, Zimmet P, Shaw J; IDF Epidemiology Task Force Consensus Group. The metabolic syndrome--a new worldwide definition. Lancet. 200530;366(9491):1059-62.

13. Després JP, Lemieux I. Abdominal obesity and metabolic syndrome. Nature. 2006;444(7121):881-7.

14. Rodriguez BL, D'Agostino R, Abbott RD, Kagan A, Burchfiel CM, Yano K, Ross GW, Silbershatz H, Higgins MW, Popper J, Wolf PA, Curb JD. Risk of hospitalized stroke in men enrolled in the Honolulu Heart Program and the Framingham Study: A comparison of incidence and risk factor effects. Stroke. 2002;33(1):230-6.

15. Brown CD, Higgins $M$, Donato KA, Rohde FC, Garrison R, Obarzanek E, Ernst ND, Horan M. Body mass index and the prevalence of hypertension and dyslipidemia. Obes Res. 2000;8(9):605-19.

16. Kondo H, Ninomiya T, Hata J, Hirakawa Y, Yonemoto K, Arima H, Nagata M, Tsuruya K, Kitazono T, Kiyohara $Y$. Angiotensin I-converting enzyme gene polymorphism enhances the effect of hypercholesterolemia on the risk of coronary heart disease in a general Japanese population: the hisayama study. J Atheroscler Thromb. 2015;22(4):390-403.

17. Purkait P, Halder K, Thakur S, Ghosh Roy A, Raychaudhuri P, Bhattacharya S, Sarkar BN, Nai$d u J M$. Association of angiotensinogen gene SNPs and haplotypes with risk of hypertension in eastern Indian population. Clin Hypertens. 2017;23:12.

18. Mulder HJ, van Geel PP, Schalij MJ, van Gilst WH, Zwinderman AH, Bruschke A V G. DD ACE genepolymorphism is associated with increased coronary artery endothelial dysfunction: the PREFACE trial. Heart. 2003; 89(5): 557-8.

19. Sakhteh M, Poopak B, Amirizadeh N, Shamshiri A, Bagheri A, Faranoush M. Polymorphism and synergism of angiotensin-converting enzyme (ACE) and plasminogen activator inhibitor-1 (PAI-1) genes in coronary artery disease. $J$ Renin Angiotensin Aldosterone Syst. 2015;16(4):1168-74.

20. Keavney B, McKenzie C, Parish S, Palmer A, Clark S, Youngman L, Delépine M, Lathrop M, Peto R, Collins $R$. Large-scale test of hypothesised associations between the angiotensin-converting-enzyme insertion/deletion polymorphism and myocardial infarction in about 5000 cases and 6000 controls. International Studies of Infarct Survival (ISIS) Collaborators. Lancet. 2000;355(9202):434-42.

21. Govindaraju DR, Adrienne Cupples L, Kannel WB, O'Donnell CJ, Atwood LD, D'Agostino RB Sr, Fox CS, Larson M, Levy D, Murabito J, Vasan RS, Lee Splansky G, Wolf PA, Benjamin EJ. Genetics of the Framingham Heart Study population. Adv Genet. 2008;62:33-65.

22. Kotlovskii MYu, Kotlovskaya OS, Osedko OYa, Kirichenko DS, Pokrovskii AA, Osedko AV, Govorun VM, Kotlovskii YuV. Polimorfizm gena angiotenzin-prevrashchayushchego fermenta u lyudei s gipertonicheskoi bolezn'yu i khronicheskoi formoi IBS. Fundamental Res. 2011;11(1):49-52.

23. Tseluyko VI, Bregvadze TR, Mishchuk NE, Vashakidze ZS. Angiotensin II type 1 receptor gene polymorphism and its influence upon efficiency of olmesartan treatment in patients with essential hypertension. Ukr Cardio J. 2013; 4:21-7.

24. Bonnardeaux A, Davies E, Jeunemaitre X, Féry I, Charru A, Clauser E, Tiret L, Cambien F, Corvol P, 
Soubrier F. Angiotensin II type 1 receptor gene polymorphisms in human essential hypertension. Hypertension. 1994;24(1):63-9.

25. Buraczyńska M, Pijanowski Z, Spasiewicz D, Nowicka T, Sodolski T, Widomska - Czekajska T, Ksiazek $A$. Renin-angiotensin system gene polymorphisms: assessment of the risk of coronary heart disease. Kardiol Pol. 2003;58(1):1-9.

26. Dickson ME, Sigmund CD. Genetic basis of hypertension: revisiting angiotensinogen. Hypertension. 2006;48(1):14-20.

27. Sethi AA, Nordestgaard BG, Grønholdt ML, Steffensen R, Jensen G, Tybjaerg-Hansen A. Angiotensinogen single nucleotide polymorphisms, elevated blood pressure, and risk of cardiovascular disease. Hypertension. 2003;41(6):1202-11.

28. van Rijn MJ, Bos MJ, Isaacs A, Yazdanpanah $M$, Arias-Vásquez A, Stricker BH, Klungel OH, Oostra BA, Koudstaal PJ, Witteman JC, Hofman A, Breteler MM, van Duijn CM. Polymorphisms of the renin-angiotensin system are associated with blood pressure, atherosclerosis and cerebral white matter pathology. J Neurol Neurosurg Psychiatry. 2007;78(10):1083-7.

29. Ji LD, Zhang LN, Shen P, Wang P, Zhang YM, Xing $W H, X u J$. Association of angiotensinogen gene M235T and angiotensin-converting enzyme gene I/D polymorphisms with essential hypertension in Han Chinese population: a meta-analysis. J Hypertens. 2010;28(3):419-28.

30. Cheng JL, Wang AL, Wan J. Association between the M235T polymorphism of the AGT gene and cytokines in patients with hypertension. Exp Ther Med. 2012;3(3):509-512.

31. Kuhlencordt PJ, Gyurko R, Han F, Scherrer-Crosbie M, Aretz TH, Hajjar R, Picard MH, Huang PL. Accelerated atherosclerosis, aortic aneurysm formation, and ischemic heart disease in apolipoprotein E/endothelial nitric oxide synthase double-knockout mice. Circulation. 2001;104(4):448-54.

32. Marsden PA, Heng HH, Scherer SW, Stewart RJ, Hall AV, Shi XM, Tsui LC, Schappert KT. Structure and chromosomal localization of the human constitutive endothelial nitric oxide synthase gene. J Biol Chem. 1993;268(23):17478-88.
33. Zhang R, Min $W$, Sessa WC. Functional analysis of the human endothelial nitric oxide synthase promoter. Sp1 and GATA factors are necessary for basal transcription in endothelial cells. J Biol Chem. 1995;270(25):15320-6.

34. Hyndman ME, Parsons HG, Verma S, Bridge PJ, Edworthy $S$, Jones $C$, Lonn E, Charbonneau F, Anderson TJ. The T-786-->C mutation in endothelial nitric oxide synthase is associated with hypertension. Hypertension. 2002;39(4):919-22.

35. Alvarez R, González P, Batalla A, Reguero JR, Iglesias-Cubero G, Hevia S, Cortina A, Merino E, González I, Alvarez V, Coto E. Association between the NOS3 (-786 T. C) and the ACE (I. D) DNA genotypes and early coronary artery disease. Nitric Oxide. 2001;5(4):343-8.

36. Casas JP, Bautista LE, Humphries SE, Hingorani $A D$. Endothelial nitric oxide synthase genotype and ischemic heart disease: meta-analysis of 26 studies involving 23028 subjects. Circulation. 2004;109(11):1359-65.

37. Kobashi G, Yamada H, Ohta K, Kato E, Ebina Y, Fujimoto $S$. Endothelial nitric oxide synthase gene (NOS3) variant and hypertension in pregnancy. $\mathrm{Am}$ J Med Genet. 2001;103(3):241-4.

38. Dias RG, Gowdak MM, Pereira AC. Genetics and cardiovascular system: influence of human genetic variants on vascular function. Genes Nutr. 2011;6(1):55-62.

39. Sakar MN, Atay AE, Demir S, Bakir VL, Demir B, Balsak D, Akay E, Ulusoy AI, Verit FF. Association of endothelial nitric oxide synthase gene G894T polymorphism and serum nitric oxide levels in patients with preeclampsia and gestational hypertension. J Matern Fetal Neonatal Med. 2015;28(16):1907-11.

40. Mackawy AM, Khan AA, Badawy Mel-S. Association of the endothelial nitric oxide synthase gene G894T polymorphism with the risk of diabetic nephropathy in Qassim region, Saudi Arabia-A pilot study. Meta Gene. 2014;2:392-402. ubMed

41. Katakami N, Kaneto H, Matsuoka TA, Takahara M, Osonoi T, Saitou M, Kawai K, Ishibashi F, Kashiwagi A, Kawamori R, Shimomura I, Yamasaki Y. Accumulation of oxidative stress-related gene polymorphisms and the risk of coronary heart disease events 
in patients with type 2 diabetes--an 8-year prospective study. Atherosclerosis. 2014;235(2):408-14.

42. Joshi MS, Wattanapitayakul S, Schanbacher BL, Bauer JA. Effects of human endothelial gene polymorphisms on cellular responses to hyperglycaemia: role of NOS3 (Glu298Asp) and ACE (I/D) polymorphisms. Diab Vasc Dis Res. 2011;8(4):276-83.

43. Kuznetsova TY, Gavrilov DV, Samokhodskaya LM, Postnov AYu, Boitsov SA. Influence of polymorphism glu298asp of gene of endothelial NO-2 synthase on the development of target organs damage in the establishment of arterial hypertension at an early age. Sibir Med J. 2010; 25(2-1):33-8.

44. Grøntved A, Andersen LB, Franks PW, Verhage B, Wareham NJ, Ekelund U, Loos RJ, Brage S. NOS3 variants, physical activity, and blood pressure in the European Youth Heart Study. Am J Hypertens. 2011;24(4):444-50.

45. Martínez-Godínez Á, Miliar-García Á, BautistaJiménez MI, Jandete-Rivera F, Vera-Lastra OL, Jara LJ, Bizueto-Rosas H, del Pilar Cruz-Domínguez $M$. [Carotid and brachial intima-media thickness of the allelic variants G894T and T-789C of eNOS in systemic sclerosis patients]. Rev Med Inst Mex Seguro Soc. 2015;53 Suppl 1:S46-52.

46. García-González I, Solís-Cárdenas A, Flores-Ocampo JA, Alejos-Mex R, Herrera-Sánchez LF, González-Herrera LJ. G894T (NOS3) and G1958A (MTHFD1) gene polymorphisms and risk of ischemic heart disease in Yucatan, Mexico. Cline Investig Arterioscler. 2015; 27(2): 64-73.

47. Guo X. Endothelial nitric oxide (eNOS) gene G894T and VNTR polymorphisms are closely associated with the risk of ischemic stroke development for Asians: meta-analysis of epidemiological studies. Mol Biol Rep. 2014;41(4):2571-83.

48. Liu J, Wang L, Liu Y, Wang Z, Li M, Zhang B, Wang $H$, Liu K, Wen $S$. The association between endothelial nitric oxide synthase gene G894T polymorphism and hypertension in Han Chinese: a casecontrol study and an updated meta-analysis. Ann Hum Biol. 2015;42(2):184-94.

49. Wrzosek M, Sokal M, Sawicka A, Wlodarczyk M, Glowala M, Wrzosek M, Kosior M, Talalaj M, BiecekP, Nowicka $G$. Impact of obesity and nitric oxide synthase gene G894T polymorphism on essential hypertension. J Physiol Pharmacol. 2015; 66(5):681-9.

50. Nasr HB, Dimassi S, M'hadhbi R, Debbabi H, Kortas M, Tabka Z, Chahed K. Functional G894T (rs1799983) polymorphism and intron-4 VNTR variant of nitric oxide synthase (NOS3) gene are susceptibility biomarkers of obesity among Tunisians. Obes Res Clin Pract. 2016;10(4):465-75.

51. Kravchenko NA, Iarmysh NV. [Regulation of endothelial NO-synthase expression and vascular endothelium dysfunction in cardiovascular pathology]. Tsitol Genet. 2008;42(4):69-81.

52. Fatini C, Sofi F, Sticchi E, Gensini F, Gori AM, Fedi S, Lapini I, Rostagno C, Comeglio M, Brogi D, Gensini $G$, Abbate R. Influence of endothelial nitric oxide synthase gene polymorphisms (G894T, 4a4b, $\mathrm{T}-786 \mathrm{C}$ ) and hyperhomocysteinemia on the predisposition to acute coronary syndromes. Am Heart $J$. 2004;147(3):516-21.

53. Tong Y, Yin X, Wang Z, Zhan F, Zhang Y, Ye J, Hou S, Geng Y, Li Y, Guan X, Jiang Y, Zhang L, Dai J, Mason KA, Liu J, Lu Z, Cheng J. A tailed primers protocol to identify the association of eNOS gene variable number of tandem repeats polymorphism with ischemic stroke in Chinese Han population by capillary electrophoresis. Gene. 2013;517(2):218-23.

54. Rossi GP, Taddei S, Virdis A, Cavallin M, Ghiadoni L, Favilla S, Versari D, Sudano I, Pessina AC, Salvetti $A$. The T-786C and Glu298Asp polymorphisms of the endothelial nitric oxide gene affect the forearm blood flow responses of Caucasian hypertensive patients. J Am Coll Cardiol. 2003;41(6):938-45.

55. Naber ChK, Frey UH, Oldenburg O, Brauck K, Eggebrecht H, Schmermund A, Baumgart D, Erbel R, Siffert W, Heusch G. Relevance of the NOS3 $\mathrm{T}-786 \mathrm{C}$ and G894T variants for cholinergic and adrenergic coronary vasomotor responses in man. Basic Res Cardiol. 2005;100(5):453-60.

56. Gomma AH, Elrayess MA, Knight CJ, Hawe E, Fox KM, Humphries SE. The endothelial nitric oxide synthase (Glu298Asp and -786T $>$ C) gene polymorphisms are associated with coronary in-stent restenosis. Eur Heart J. 2002;23(24):1955-62.

57. Degaeva TA, Radajkina OG, Usanova AA, Goncharova LN, Antipova VN, Fazlova IH, Guranova NN. 
Polimorfizm gena jendotelial'noj sintazy oksida azota-3 u bol'nyh arterial'noj gipertoniej i saharnym diabetom II tipa, prozhivajushhih na territorii respubliki Mordovija. Mordovia University Bulletin. 2013; 1-2: 53-6.

58. Bebjakova NA, Hromova AV, Feliksova OM. Vzaimosvjaz' perifericheskoj vazokonstrikcii s polimorfizmom T-786S gena jendotelial'noj sintazy oksida azota. Fundamental'nye issledovanija. 2013; 12(2); 176-9.

59. Casas JP, Cavalleri GL, Bautista LE, Smeeth L, Humphries SE, Hingorani AD. Endothelial nitric oxide synthase gene polymorphisms and cardiovascular disease: a HuGE review. Am J Epidemiol. 2006;164(10):921-35.

60. Hyndman ME, Parsons HG, Verma S, Bridge PJ, Edworthy S, Jones C, Lonn E, Charbonneau F, Anderson TJ. The T-786-->C mutation in endothelial nitric oxide synthase is associated with hypertension. Hypertension. 2002;39(4):919-22.

61. Liu CS, Huang RJ, Sung FC, Lin CC, Yeh CC. Association between endothelial nitric oxide synthase polymorphisms and risk of metabolic syndrome. Dis Markers. 2013;34(3):187-97.

62. Bressler J, Pankow JS, Coresh J, Boerwinkle E. Interaction between the NOS3 gene and obesity as a determinant of risk of type 2 diabetes: the Atherosclerosis Risk in Communities study. PLoS One. 2013;8(11):e79466.

63. Colombo $M G$, Paradossi U, Andreassi $M G$, Botto $N$, Manfredi S, Masetti S, Biagini A, Clerico A. Endothelial nitric oxide synthase gene polymorphisms and risk of coronary artery disease. Clin Chem. 2003;49(3):389-95.

64. Vecchione C, Villa F, Carrizzo A, Spinelli CC, Damato A, Ambrosio M, Ferrario A, Madonna $M$, Uccellatore A, Lupini S, Maciag A, Ryskalin L, Milanesi L, Frati G, Sciarretta S, Bellazzi R, Genovese $S$, Ceriello A, Auricchio A, Malovini A, Puca AA. A rare genetic variant of BPIFB4 predisposes to high blood pressure via impairment of nitric oxide signaling. Sci Rep. 2017;7(1):9706.

65. Akilzhanova A, Kozhamkulov U, Kairov U, Rakhimova S, Akhmetova A, Yerezhepov D, Molkenov A, Abilova1 Z, Zhumadilov Z. Determination of genetic variants associated with hypertension, obesity and diabetes in Kazakh population to study interaction of genetic variants and metabolome. Meditsina i Zdravoohranenie. 2016; 5: 30-42.

66. Kim YK, Hwang MY, Kim YJ, Moon S, Han S, Kim BJ. Evaluation of pleiotropic effects among common genetic loci identified for cardio-metabolic traits in a Korean population. Cardiovasc Diabetol. 2016;15:20.

\section{Поліморфізм генів ренін-ангіотензинової системи та гена ендотеліальної по-синтази у хворих на артеріальну гіпертензію з ожирінням}

Т. В. Ащеулова, Н. М. Герасимчук,

Г. В. Демиденко, М. В. Кулікова

У статті представлений клінічно встановлений взаємозв'язок підвищеного артеріального тиску зі збільшенням маси тіла. Показано, що ендотеліальна дисфункція і дисбаланс нейро-гуморальних систем, а саме патологічне підвищення активності ренін-ангіотензинової системи, виступають провідними механізмами патогенезу гіпертонічної хвороби в поєднанні з ожирінням. Даний огляд літератури присвячений інтерпретації наукових досліджень в області поліморфізму генів ренін ангіотензинової системи і гена ендотеліальної синтази оксиду азоту. Складність полягає в правильній оцінці асоціацій алелей, які мають клінічне значення. Особливо важливо завжди точно визначати асоціації поліморфізму генів при гіпертонічній хворобі з ожирінням. Інформація про подібні асоціації і зв'язки надає можливість для пошуку нових тактик i мішеней впливу, що розвиває персоніфіковані підходи до терапії пацієнтів 3 даною комплексною патологією.

К л ю ч о в і с с о в а: ендотеліальна синтаза оксиду азоту, ренін-ангітензінова система, поліморфізм генів, гіпертонічна хвороба, ожиріння.

\section{Полиморфизм генов ренин-ангиотензиновой системы и гена эндотелиальной по-синтазы у больных артериальной гипертензией с ожирением}

Т. В. Ащеулова, Н. Н. Герасимчук, А. В. Демиденко, М. В. Куликова

В статье представлены данные о взаимосвязи повышения уровня артериального давления и увеличения 
массы тела. Показано, что эндотелиальная дисфункция и дисбаланс нейрогуморальных систем, а именно патологическое повышение активности ренин-ангиотензиновой системы выступают ведущими механизмами патогенеза гипертонической болезни в сочетании с ожирением. Данный обзор литературы посвящён интерпретации научных изысканий в области полиморфизма генов ренин ангиотензиновой системы и гена эндотелиальной синтазы оксида азота. Трудность заключается в правильной оценке ассоциаций аллелей, которые имеют клиническое значение. Особенно важно точное определение ассоциаций полиморфизма генов при гипертонической болезни с ожирением. Информация о подобных ассоциациях и связях предоставляет возможности для поиска новых тактик и мишеней для воздействия, что развивает персонифицированные подходы к терапии пациентов с данной комплексной патологией.

К л ю ч е в ы е с л о в а: эндотелиальная синтаза оксида азота, ренин-ангитензиновая система, полиморфизм гена, гипертоническая болезнь, ожирение.

Receivwd 26.06.2018 